\title{
Stable levels of Coxiella burnetii prevalence in dairy sheep flocks but changes in genotype distribution after a 10-year period in northern Spain
}

\author{
Raquel Álvarez-Alonso' ${ }^{1}$ Jesús Felix Barandika ${ }^{1}$, Francisco Ruiz-Fons ${ }^{2}$, Ione Ortega-Araiztegi ${ }^{1}$, Isabel Jado ${ }^{3}$, \\ Ana Hurtado ${ }^{1}$ and Ana Luisa García-Pérez ${ }^{1 *}$ (1)
}

\begin{abstract}
Bulk tank milk (BTM) samples were collected from 81 sheep flocks in the Basque Country, Spain, in 2015 and were analysed for antibodies against Coxiella burnetii by ELISA and for C. burnetii DNA by real-time PCR. Thirty-two percent of the flocks had BTM antibodies against C. burnetii. Presence of C. burnetii DNA in BTM was detected in 23\% of the flocks, suggesting recent C. burnetii infections. Retrospective data of BTM samples obtained from 154 sheep flocks investigated in 2005 in the same geographic area were compiled to assess temporal changes in C. burnetii infection. The overall percentage of infected sheep flocks did not significantly change after the 10-year period. Among the 46 flocks sampled in both periods, 11 flocks that were negative in 2005 were positive in 2015, 18 maintained their initial status (positive or negative), and 17 positive flocks were negative in 2015. These findings indicate that C. burnetii infection is a dynamic process in dairy sheep in northern Spain. Single nucleotide polymorphism (SNP) genotyping of positive samples identified three genotypes, SNP1 being the most prevalent in 2015 and SNP8 in 2005; SNP4 was only detected once in 2005. These results suggest possible changes in the pattern of genotype infection over time.
\end{abstract}

Keywords: Coxiella burnetii, Dairy sheep, Bulk tank milk, SNP genotyping

\section{Findings}

Q fever is a worldwide distributed zoonosis caused by Coxiella burnetii. Domestic ruminants are the main reservoir and source of infection for humans [1]. C. burnetii can produce abortion in domestic ruminants such as cattle, sheep and goats [2]. To prevent Q fever outbreaks both in animals and in people, it is important to monitor the presence and prevalence of C. burnetii in livestock farms to establish effective control measures. Serological tests on bulk tank milk (BTM) samples are very useful for the epidemiological surveillance of some infections in dairy livestock. In the case of C. burnetii, detection of

\footnotetext{
*Correspondence: agarcia@neiker.eus

${ }^{1}$ NEIKER - Instituto Vasco de Investigación y Desarrollo Agrario, Animal Health Department, Bizkaia Science and Technology Park 812L, 48160 Derio, Biscay, Spain

Full list of author information is available at the end of the article
}

antibodies in BTM is indicative of previous contact of the herd with the pathogen, whereas detection of the pathogen would be indicative of a current and active infection. The evolution of infection can be also monitored by periodic analyses of BTM samples, as shown for dairy cattle [3] and goats [4]. C. burnetii DNA obtained from positive BTM samples can be genotyped to determine strains present $[5,6]$.

In the Basque Country, northern Spain, dairy sheep attains both the highest $C$. burnetii flock seroprevalence $(74 \%)$ and the highest within-flock seroprevalence $(11.8 \%)$ compared to other domestic ruminants [7], suggesting that sheep could be the main reservoir of infection in this area. Lambing in Latxa sheep flocks occurs once a year with an early peak between November and February for ewes in their second and subsequent lactations and a second peak in March-April for yearlings. 
Lambing is followed by a milking period of 3-4 months. Once milking finishes, many flocks have access to communal mountain pastures during summer and autumn where they widely interact with other grazing sheep flocks, goats, cattle and wildlife. According to the last census (2015) there were 259,569 Latxa breed sheep in northern Spain, showing a reduction of $30 \%$ in the last 10 years (354,445 sheep in 2005) (http://www.eustat.eus/ banku/id_4017/indexLista.html). A survey carried out in 2005 in 154 dairy sheep flocks indicated that C. burnetii was actively circulating in the region [8]. In this context, 10 years later, this study was aimed at (i) identifying changes in the prevalence of $C$. burnetii in dairy sheep after a period of 10 years in the area, and (ii) characterizing the genotypes infecting dairy sheep in the region in both time points to evaluate changes over time. No compulsory control actions against Q fever had been taken during the 10-year period.

BTM samples were collected from 81 sheep farms in March-April 2015, when both, ewes and yearlings, were being milked. Serological analyses were performed by an enzyme-linked immunosorbent assay (ELISA) (PrioCHECK $^{\mathrm{TM}}$ Ruminant Q Fever Ab Plate ELISA Kit, Thermo Fisher Scientific, USA) according to the manufacturer's instructions. DNA was extracted using the QIAmp DNA Blood Mini Kit (Qiagen Hilden, Germany), with modifications already described [3], and presence of C. burnetii DNA was investigated by real-time polymerase chain reaction (rt-PCR) amplification targeting the transposon-like repetitive region IS1111 of C. burnetii [9], including a commercial internal amplification control (TaqMan ${ }^{\circledR}$ Exogenous Internal Positive Control, Thermo Fisher Scientific) to monitor for PCR inhibitors.

The percentage of flocks with antibodies against $C$. burnetii in BTM samples was $32.1 \%$ (26/81) and the percentage of flocks with C. burnetii DNA in milk was 23.5\% (19/81). Three flocks were BTM negative by ELISA but low levels of bacterial shedding were detected by rt-PCR (Ct 33-35).

In order to assess changes in C. burnetii infection after a 10-year period, BTM ELISA and PCR results from 154 sheep flocks sampled in March-April 2005 [8, 10] were compiled and Chi-square tests were used to compare infection prevalence (2015 vs. 2005). The ELISA test used in both studies was the same (commercialized by LSI, France in 2005), but the PCR method differed (conventional PCR was used in 2005, rt-PCR in 2015). The number of sheep flocks surveyed in both studies represented $30 \%$ of the professionally managed flocks with over 100 reproductive ewes in the study region. ELISA and PCR results obtained in 2015 did not significantly differ from those obtained in 2005 (Table 1). However, a slight decrease in the prevalence of flocks with antibodies against C. burnetii ( $40.3 \%$ in 2005 vs. $32.1 \%$ in 2015 ; $\left.X^{2}=1.51, \mathrm{df}=1, \mathrm{P}>0.05\right)$ and a slight increase in the percentage of flocks with C. burnetii DNA in the BTM were observed $\left(22.1 \%\right.$ in 2005 vs. $23.5 \%$ in $2015 ; X^{2}=0.06$, $\mathrm{df}=1, \mathrm{P}>0.05$ ).

Comparison of both series of data identified 46 flocks which were sampled in both surveys. Again, non-significant differences similar to those described for the whole dataset of farms were observed when considering seroprevalence $\left(43.5 \%\right.$ in 2005 vs. $37.0 \%$ in $2015 ; \chi^{2}=0.41$, $\mathrm{df}=1, \mathrm{P}>0.05)$ or bacterial (DNA) shedding $(21.7 \%$ in 2005 vs. $28.3 \%$ in $\left.2015 ; \mathrm{X}^{2}=0.47, \mathrm{df}=1, \mathrm{P}>0.05\right)$. The different molecular techniques used in both periods, conventional PCR vs. rt-PCR, the latter being more sensitive [11], could have contributed to the slight but non-significant increase in shedding. Unfortunately, the small amount of DNA available from BTM samples collected in 2005 prevented us from reanalysing them with rt-PCR. Changes in the C. burnetii status of some flocks were observed between samplings when considering a flock as "negative" when BTM was negative by ELISA and PCR, and as "positive" when positive by ELISA or PCR (Table 2). Thus, 11 flocks that were negative in 2005 were positive in 2015, 18 maintained their initial status (positive or negative), and 17 positive flocks were negative in 2015. Interestingly, 8 of the 25 positive flocks in 2005 were still positive in 2015 . Had vaccination been implemented, the prevalence of C. burnetii might have decreased significantly as happened in The Netherlands [4]. In the region of the current study, an inactivated vaccine has only been used at an individual basis by a scarce

Table 1 Percentage of Coxiella burnetii positive flocks and SNP genotypes identified in bulk tank milk samples collected in 2005 and 2015 in northern Spain

\begin{tabular}{|c|c|c|c|c|c|c|c|c|c|}
\hline \multicolumn{5}{|c|}{ BTM analyses } & \multicolumn{5}{|c|}{ Single nucleotide polymorphism (SNP) } \\
\hline \multirow[t]{2}{*}{ Year } & \multirow[t]{2}{*}{$\mathbf{N}$} & \multirow{2}{*}{$\begin{array}{l}\text { ELISA } \\
\text { Positive (\%) }\end{array}$} & \multirow{2}{*}{$\begin{array}{l}\text { PCR } \\
\text { Positive (\%) }\end{array}$} & \multirow[t]{2}{*}{ Ref. } & \multirow[t]{2}{*}{$\mathbf{N}$} & \multirow{2}{*}{$\begin{array}{l}\text { SNP1 } \\
\text { Positive (\%) }\end{array}$} & \multirow{2}{*}{$\begin{array}{l}\text { SNP4 } \\
\text { Positive (\%) }\end{array}$} & SNP8 & \multirow[t]{2}{*}{ Ref. } \\
\hline & & & & & & & & Positive (\%) & \\
\hline 2005 & 154 & $62(40.3 \%)$ & $34(22.1 \%)$ & {$[8,10]$} & 16 & $3(18.8 \%)$ & $1(6.3 \%)$ & $12(75.0 \%)$ & This study \\
\hline 2015 & 81 & $26(32.1 \%)$ & $19(23.5 \%)$ & This study & 12 & $10(83.3 \%)$ & $0(0.0 \%)$ & $2(16.7 \%)$ & This study \\
\hline
\end{tabular}


Table 2 Coxiella burnetii infection status in 2005 and 2015 of the $\mathbf{4 6}$ sheep flocks from northern Spain analysed in both periods

\begin{tabular}{lll}
\hline $\begin{array}{l}\text { Numbers of examined sheep } \\
\text { flocks }\end{array}$ & $\begin{array}{l}\text { C. burnetii status } \\
\text { in 2005 }\end{array}$ & $\begin{array}{l}\text { C. burnetii } \\
\text { status } \\
\text { in } \mathbf{2 0 1 5}\end{array}$ \\
\hline 11 & Negative & Positive \\
10 & Negative & Negative \\
17 & Positive & Negative \\
8 & Positive & Positive \\
\hline
\end{tabular}

number of sheep breeders and no specific collective control actions were implemented from 2015 to 2015. The results may suggest that infectious stages of $C$. burnetii persisted in the farm environments during this period in the 8 flocks that remained positive. Alternatively, reinfections could have also occurred during this 10 -year period e.g., due purchase of infected animals, contact with other infected flocks, wildlife, etc., with an unnoticed period of infection clearance between samplings.
Geographical coordinates of the 46 farms sampled in 2005 and 2015 were recorded using a global positioning system (GPS) device. Data on Q-fever status of each flock (positive/negative) were geographically represented using QGIS Las Palmas 2.18.16 Geographical Information System to visualize changes in the spatial distribution of $C$. burnetii overtime (Fig. 1). Considering that C. burnetii can be dispersed by the wind, flocks in the vicinity of a positive flock would be expected to be also positive. However, in 2005, negative and positive farms were homogeneously located throughout the sampled territory. Conversely, in 2015, infection seemed to have cleared in some flocks from the eastern part of the region. Mapping the epidemiological status of $C$. burnetii in the studied flocks showed that in some areas the infection seemed to clear out without specific control measures while in other areas it seemed to persist for years. The analysis of more than one BTM sample per lactation period and additional intermediate controls during the 10-year timeframe should have been performed to get more accurate data on C. burnetii persistence over time. However, this was a first approach using this methodology that will be

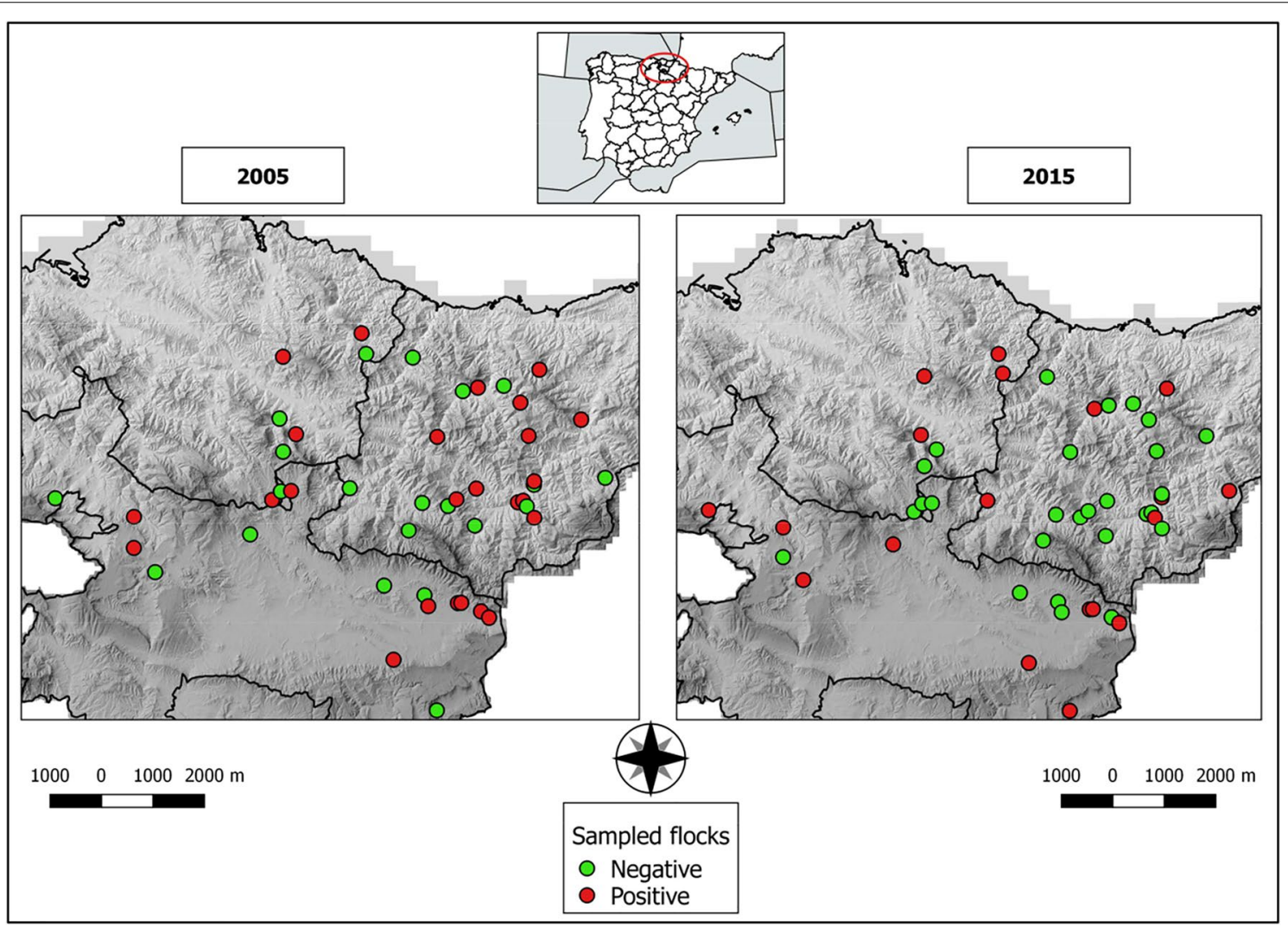

Fig. 1 Spatial geographical location of 46 sheep farms in northern Spain sampled in 2005 and 2015 and their Coxiella burnetii status. Negative flocks (ELISA and PCR negative on bulk tank milk) are represented as green dots, where as positive flocks (ELISA and/or PCR BTM-positive) are shown as red dots 
further developed for the evaluation of the efficacy of vaccination-based control measures that will be soon implemented in the Basque Country, Spain.

A subset of rt-PCR positive samples with a $\mathrm{Ct}<31$ was selected and genotyped by single nucleotide polymorphism (SNP) analysis, implementing the 10 SNP determination already described [12], a highly discriminatory technique that has demonstrated to be valuable for direct genotyping of field samples with low bacterial burdens, such as milk samples [12]. A total of $28 \mathrm{rt}-\mathrm{PCR}$ positive samples were genotyped, 16 from 2005 and 12 from 2015, all from different flocks. Three SNP genotypes were identified: SNP1 and SNP8, found both in 2005 and 2015, and SNP4, found only once in 2005 (Table 1). Genotype SNP1 has been detected in goats, sheep, or cattle in several countries such as France, Belgium and The Netherlands $[5,12,13]$, and in human patients in the $Q$ fever outbreak from the Netherlands [12]. SNP8 has been described in human infections in Italy and Slovakia, and has been also found in ticks from Russia, and in ticks and small mammals from Slovakia [12]. Recently, we found SNP1 (MST13) and SNP8 (MST18) in Spanish goat farms identified as the most probable sources of two outbreaks of $\mathrm{Q}$ fever infections in humans experiencing fever and pneumonia $[14,15]$. Therefore, sheep carrying $C$. burnetii genotypes SNP1 and SNP8 could also pose a risk for human infections in the study area. Comparison of frequencies of genotypes by Chi-square tests revealed that distribution of SNP genotypes changed significantly in the two periods. Hence, whereas in 2005 SNP8 was the predominant type (12/16), in 2015 SNP1 was the most prevalent $(10 / 12)$ (Fisher exact test, $\mathrm{P}<0.01)$, indicating changes in the pattern of genotype infection over time, possibly due to the infection by co-circulating C. burnetii strains, and/or the evolution of previously detected strains [16]. In fact, the presence of multiple C. burnetii strains within a single sheep flock has been reported previously [17]. Also, SNP1 dominance in 2015 might be the result of a recent adaptation of this genotype in sheep and a rapid dispersal within the sheep population. However, this hypothesis should be confirmed in further studies. Interestingly, SNP4, recovered from human blood in Slovakia [12], was also identified in one flock in 2005 and was not detected thereafter. These results show the importance of understanding the natural dynamics of this zoonotic pathogen in its major reservoirs to efficiently prevent the negative effects caused by $\mathrm{Q}$ fever to animal production and public health.

In conclusion, $C$. burnetii infection presents a dynamic pattern in the studied sheep population. However, the observed trend indicated a stability in the overall percentage of infected sheep flocks in a region where no collective intervention measures have been yet implemented.
The analysis of BTM samples in dairy ruminants is an easy strategy to identify infected flocks. Antibody levels in BTM are consistent with findings in serum of dairy ewes over time [18]. In addition, PCR analysis of BTM allows identification of animal shedders in the flock [8], but only if BTM samples are collected soon after the start of the milking period of ewes and yearlings since $C$. burnetii shedding through milk in small ruminants is shorter compared to other excretion routes $[14,18]$.

\section{Abbreviations \\ BTM: bulk tank milk; Ct: cycle threshold; ELISA: enzyme-linked immuno- sorbent assay; GPS: global positioning system; MST: multispacer sequence typing; rt-PCR: real time polymerase chain reaction; SNP: single nucleotide polymorphism.}

\section{Authors' contributions}

RAA carried out the laboratorial work and drafted the manuscript. IJ supervised genotyping work. IOA compiled GPS coordinates and made the positioning maps. FRF analyzed and interpreted the data. AH assisted with the interpretation and discussion of results and correcting the manuscript. ALG is head of the project and had primary responsibility for the investigations reported here and together with JFB planned and designed the study. All authors read and approved the final manuscript.

\section{Author details}

${ }^{1}$ NEIKER - Instituto Vasco de Investigación y Desarrollo Agrario, Animal Health Department, Bizkaia Science and Technology Park 812L, 48160 Derio, Biscay, Spain. ${ }^{2}$ Animal Health and Biotechnology Group (SaBio), Instituto de Investigación en Recursos Cinegéticos IREC (CSIC-UCLM-JCCM), Ciudad Real, Spain. ${ }^{3}$ Centro Nacional de Microbiología - Instituto de Salud Carlos III, Majadahonda, Madrid, Spain.

\section{Acknowledgements}

We thank farmers for their collaboration. We acknowledge our colleagues from the Animal Health Diagnostic laboratory at NEIKER for helping us with serological work.

\section{Competing interests}

The authors declare that they have no competing interests.

\section{Availability of data and materials}

All data generated or analysed during this study are included in this article. The data are available from the corresponding author upon reasonable request.

\section{Ethics approval and consent to participate} Not applicable.

\section{Funding}

This work was funded by INIA (RTA2013-00051-C02-00), FEDER funds and the Basque Government. RAA is beneficiary of a Ph.D. contract funded by INIA (FPI-2015-014). FRF is funded by the Spanish Ministry for the Economy, Industry and Competitiveness (MINECO) through a contract under the Ramón y Cajal program.

\section{Publisher's Note}

Springer Nature remains neutral with regard to jurisdictional claims in published maps and institutional affiliations.

Received: 3 August 2018 Accepted: 13 November 2018 Published online: 20 November 2018 


\section{References}

1. Eldin C, Melenotte C, Mediannikov O, Ghigo E, Million M, Edouard S, Mege JL, Maurin M, Raoult D. From Q fever to Coxiella burnetii infection: a paradigm change. Clin Microbiol Rev. 2017;30:115-90.

2. Agerholm JS. Coxiella burnetii associated reproductive disorders in domestic animals - a critical review. Acta Vet Scand. 2013;55:13.

3. Piñero A, Ruiz-Fons F, Hurtado A, Barandika JF, Atxaerandio R, Garcia-Perez AL. Changes in the dynamics of Coxiella burnetii infection in dairy cattle: an approach to match field data with the epidemiological cycle of $C$. burnetii in endemic herds. J Dairy Sci. 2014;97:2718-30.

4. van den Brom R, Santman-Berends I, Luttikholt S, Moll L, van Engelen E, Vellema P. Bulk tank milk surveillance as a measure to detect Coxiella burnetii shedding dairy goat herds in The Netherlands between 2009 and 2014. J Dairy Sci. 2015;98:3814-25.

5. Dal Pozzo F, Renaville B, Martinelle L, Renaville R, Thys C, Smeets F, et al. Single nucleotide polymorphism genotyping and distribution of Coxiella burnetii strains from field samples in Belgium. Appl Environ Microbiol. 2015;82:81-6

6. Roest HI, Ruuls RC, Tilburg JJ, Nabuurs-Franssen MH, Klaassen $\mathrm{CH}$, Vellema $P$, et al. Molecular epidemiology of Coxiella burnetii from ruminants in $\mathrm{Q}$ fever outbreak, The Netherlands. Emerg Infect Dis. 2011;17:668-75.

7. Ruiz-Fons F, Astobiza I, Barandika JF, Hurtado A, Atxaerandio R, Juste RA, García-Pérez AL. Seroepidemiological study of Q fever in domestic ruminants in semi-extensive grazing systems. BMC Vet Res. 2010;6:3.

8. García-Pérez AL, Astobiza I, Barandika JF, Atxaerandio R, Hurtado A, Juste RA. Investigation of Coxiella burnetii occurrence in dairy sheep flocks by bulk-tank milk analysis and antibody level determination. J Dairy Sci. 2009;92:1581-4.

9. Schets FM, de Heer L, de Roda Husman AM. Coxiella burnetii in sewage water at sewage water treatment plants in a Q fever epidemic area. Int J Hyg Environ Health. 2013:216:698-702.

10. Ruiz-Fons F, Astobiza I, Barandika JF, Juste RA, Hurtado A, García-Pérez AL. Measuring antibody levels in bulk-tank milk as an epidemiological tool to search for the status of Coxiella burnetii in dairy sheep. Epidemiol Infect. 2011;139:1631-6.

11. Galiero A, Fratini F, Camma C, Di DM, Curini V, Baronti I, Turchi B, Cerri D. Occurrence of Coxiella burnetii in goat and ewe unpasteurized cheeses: screening and genotyping. Int J Food Microbiol. 2016;237:47-54.

12. Huijsmans CJ, Schellekens JJ, Wever PC, Toman R, Savelkoul PH, Janse I, Hermans MH. Single-nucleotide-polymorphism genotyping of a Coxiella burnetii during a Q fever outbreak in The Netherlands. Appl Environ Microbiol. 2011;77:2051-7.

13. Boarbi S, Mori M, Rousset E, Sidi-Boumedine K, van Esbroeck M, Fretin D. Prevalence and molecular typing of Coxiella burnetii in bulk tank milk in Belgian dairy goats, 2009-2013. Vet Microbiol. 2014;170:117-24.

14. Alvarez-Alonso R, Basterretxea M, Barandika JF, Hurtado A, Idiazabal J, Jado I, et al. A Q fever outbreak with a high rate of abortions at a dairy goat farm: Coxiella burnetii shedding, environmental contamination, and viability. Appl Environ Microbiol. 2018;84:e01650-18.

15. Hurtado A, Alonso E, Aspiritxaga I, López Etxaniz I, Ocabo B, Barandika JF, et al. Environmental sampling coupled with real-time PCR and genotyping to investigate the source of a $\mathrm{Q}$ fever outbreak in a work setting. Epidemiol Infect. 2017:145:1834-42.

16. Gurtler L, Bauerfeind U, Blumel J, Burger R, Drosten C, Groner A, et al. Coxiella burnetii-pathogenic agent of Q (Query) fever. Transfus Med Hemother. 2014;41:60-72

17. Joulie A, Laroucau K, Bailly X, Prigent M, Gasqui P, Lepetitcolin E, et al. Circulation of Coxiella burnetii in a naturally infected flock of dairy sheep: shedding dynamics, environmental contamination, and genotype diversity. Appl Environ Microbiol. 2015;81:7253-60.

18. Joulie A, Rousset E, Gasqui P, Lepetitcolin E, Leblond A, Sidi-Boumedine $\mathrm{K}$, Jourdain E. Coxiella burnetii circulation in a naturally infected flock of sheep: individual follow-up of antibodies in serum and milk. Appl Environ Microbiol. 2017;83:e00222-17.
Ready to submit your research? Choose BMC and benefit from:

- fast, convenient online submission

- thorough peer review by experienced researchers in your field

- rapid publication on acceptance

- support for research data, including large and complex data types

- gold Open Access which fosters wider collaboration and increased citations

- maximum visibility for your research: over $100 \mathrm{M}$ website views per year

At BMC, research is always in progress.

Learn more biomedcentral.com/submissions 